\title{
Day Times Micromole per Milliliter
}

National Cancer Institute

\section{Source}

National Cancer Institute. Day Times Micromole per Milliliter. NCI Thesaurus. Code C85587.

Days times micromoles per milliliter. 